\title{
The Mode of Action of Polyene Antibiotics; Induced Entry of Hydrogen Ions as a Consequence of Polyene Action on the Cell Membrane of Candida albicans
}

\author{
By S. M. HAMMOND, P. A. LAMBERT AND B. N. KLIGER \\ Division of Environmental Biology, School of Biological Sciences, \\ Thames Polytechnic, London SEI 8 6PF
}

(Received 20 June 1973; revised 9 November 1973)

\begin{abstract}
SUMMARY
The polyene antibiotic candicidin is a potent antifungal agent acting upon the cell membrane of Candida albicans. Destruction of selective permeability by polyenes allows cations to leak into the environment and permits the entry of protons to neutralize the charge so created, causing internal acidification. Quantitive studies on proton entry reveal that $\mathrm{K}^{+}$leakage alone is not sufficient to account for the degree of acidification recorded. Extracts of untreated $C$. albicans, when acidified to the same extent, precipitated. Electron micrographs of candicidin treated C. albicans cells confirm this precipitation.
\end{abstract}

\section{INTRODUCTION}

Candicidin is a polyene antibiotic important in the treatment of human mycoses particularly vaginitis caused by Candida albicans. The binding between polyene antibiotics and membrane sterols, causing membrane damage, is well documented (Lampen, 1966).

Membrane destruction leads to the loss of small ions. It was believed that the main cation lost was potassium which was replaced by protons from the environment resulting in internal acidification (Lampen, 1966). We have examined this hypothesis and investigated the effect of acidification on the cytoplasm.

\section{METHODS}

Organism and method of culture. Candida albicans NCTC7I 3 was grown on Sabouraud's dextrose agar slopes at $37{ }^{\circ} \mathrm{C}$, for $24 \mathrm{~h}$ and then maintained at $4{ }^{\circ} \mathrm{C}$. From these slopes $10^{6}$ organisms were inoculated into $100 \mathrm{ml}$ of Sabouraud's dextrose broth and incubated in shake culture for I $8 \mathrm{~h}$ at $37^{\circ} \mathrm{C}$. Organisms were harvested by centrifuging and standardized suspensions made as described previously (Hammond, Lambert \& Kliger, 1974).

Distilled water. The water used to wash and resuspend the cells was triple glass-distilled, boiled and saturated with nitrogen to ensure that it was $\mathrm{CO}_{2}$-free. This water was used for all dilutions.

Polyene antibiotic. Candicidin powder (lot 681-NOF2) was supplied by Pharmax Ltd, Bexley, Kent; it was dissolved in dimethyl sulphoxide (DMSO) and diluted with $\mathrm{CO}_{2}$-free water to give a final DMSO concentration of $\mathrm{I} \%$.

Detection of $\mathrm{pH}$ change. Standardized suspension $(40 \mathrm{ml})$, maintained at $25{ }^{\circ} \mathrm{C}$ and flushed with a stream of nitrogen, was examined with a $\mathrm{pH}$ electrode connected to a Vibret $46 \mathrm{~A}$ pH meter (E. I. L. Ltd, Chertsey, Surrey). 
Preparation of cell-free extract. Washed organisms (10 ${ }^{10}$ organisms $/ \mathrm{ml}$ ) were pressed at $-25{ }^{\circ} \mathrm{C}$ under $\mathrm{I} 2$ tonnes (X-press, A. B. Biotech, Croydon) by the method of Edebo (I96I). Larger fragments and whole organisms (approximately $8 \%$ ) were removed by centrifuging at $10000 \mathrm{~g}$ for $15 \mathrm{~min}$.

Determination of $\mathrm{pH}$ of disrupted organisms. Standardized suspension (200 $\mathrm{ml})$ was centrifuged after treatment with $20 \mu \mathrm{g}$ candicidin/ml (a known lethal dose), resuspended in I $5 \mathrm{ml}$ distilled water, disrupted by freeze pressing, made up to the original volume and the $\mathrm{pH}$ determined.

Effect of changes in $p H$ on extract of Candida albicans. An $\mathrm{I} 8 \mathrm{~h}$ culture of $C$. albicans was washed three times with distilled water by centrifuging, resuspended in $25 \mathrm{ml}$ water $\left(\mathrm{I} \cdot 6 \times 10^{8}\right.$ organisms $\left./ \mathrm{ml}\right)$ and extracted by freeze press as described (see above). The extract, diluted $\mathrm{I}$ in 4 , was placed in a flask with a side arm which allowed extinction measurements to be made with a Cecil 303 spectrophotometer. $E_{520}$ measurements were made after addition of $\mathrm{o} \cdot \mathrm{I} \mathrm{ml}$ volumes of $\mathrm{o} \cdot \mathrm{I} \mathrm{N}-\mathrm{HCl}$, and $\mathrm{pH}$ was also recorded.

Titration curves. Using preparations of disrupted organisms, titration curves were constructed to determine the buffering capacity of the cytoplasm.

Preparation for the electron microscope. Candida albicans organisms, treated and untreated, were prepared by a modification of the method of Gale (1963). Washed standardized suspensions of $C$. albicans were treated with $10 \mu \mathrm{g}$ candicidin $/ \mathrm{ml}$ (sub-lethal) or $20 \mu \mathrm{g} / \mathrm{ml}$ (lethal) for $2 \mathrm{~h}$. The pellet produced after centrifuging (20000 $\mathrm{g}$ for $30 \mathrm{~min})$ was fixed and stained with $\mathrm{r} \cdot 5 \%$ potassium permanganate for $15 \mathrm{~min}$ at $0{ }^{\circ} \mathrm{C}$. After dehydration by an alcohol series the pellet was embedded in Araldite and sections were cut on a L.K.B. ultratome and placed on Formvar-coated grids. An A.E.I. E.M.6B electron microscope was used.

\section{RESULTS}

Table I shows the changes in $\mathrm{pH}$ induced in the standardized suspension by lethal concentrations of candicidin, both externally in the supernatant and internally, i.e. changes in the cell sap. The $\mathrm{pH}$ of the cell sap of Candida albicans grown under the described conditions and determined after freeze pressing was found to be $6 \cdot 12 \pm 0.05$ ( 6 determinations).

Fig. I shows the change in the $\mathrm{H}^{+}$concentration in the suspension caused by $20 \mu \mathrm{g}$ candicidin/ml over $5 \mathrm{~h}$. From Table $\mathrm{I}$, change in the $\mathrm{pH}$ of the cell sap can be expressed in terms of $\mu$ equiv./mg dry wt (I $\mathrm{ml}$ standardized suspension contains $0.00092 \mathrm{~g}$ dry $\mathrm{wt} / \mathrm{ml})$ :

$\mathrm{pH}$ change in cell sap $=\mathrm{pH}$ of cell sap after $5 \mathrm{~h}-\mathrm{pH}$ cell sap initially

$=\mathrm{pH} 5 \cdot 20-\mathrm{pH} 6 \cdot \mathrm{I} 2$,

$\Delta\left[\mathrm{H}^{+}\right]$in cell sap $\quad=6.3 \mathrm{I} \mu$ equiv. $/ \mathrm{ml}-0.75 \mu$ equiv. $/ \mathrm{ml}$

$=5 \cdot 5 \mu$ equiv. $/ \mathrm{ml}$

$=6.05 \mu$ equiv. $/ \mathrm{mg}$ dry wt.

The number of protons leaving the suspension and entering the organisms can also be calculated:

$\mathrm{pH}$ change in the suspension

$=\mathrm{pH}$ of the suspension initially $-\mathrm{pH}$ of the suspension after $5 \mathrm{~h}$

$=\mathrm{pH} 5 \cdot 6-\mathrm{pH} 6 \cdot 5$,

$\mathrm{H}^{+}$in suspension $\quad=2.5 \mathrm{I} \mu$ equiv. $/ \mathrm{ml}-0.24 \mu$ equiv. $/ \mathrm{ml}$

$=2 \cdot 28 \mu$ equiv. $/ \mathrm{ml}$

$=2 \cdot 48 \mu$ equiv./mg dry wt. 
Table I. Changes in $\mathrm{pH}$ and hydrogen ion concentration of cell sap and a standardized suspension of Candida albicans following treatment by $20 \mu \mathrm{g}$ candicidin $/ \mathrm{ml}$

\begin{tabular}{|c|c|c|c|c|}
\hline & & & $\mathrm{Ca}$ & treated \\
\hline & $\mathrm{pH}$ & $\begin{array}{c}{\left[\mathrm{H}^{+}\right]^{*}} \\
\text { ( } \mu \text { equiv./ml) }\end{array}$ & $\mathrm{pH}$ & $\begin{array}{c}{\left[\mathrm{H}^{+}\right]^{*}} \\
(\mu \text { equiv./ml })\end{array}$ \\
\hline Suspension at $t_{0}$ & $5 \cdot 12$ & - & $5 \cdot 60$ & $2 \cdot 5 \mathrm{I}$ \\
\hline Standardized at $t_{15 \min }$ & $5 \cdot 10$ & - & $5 \cdot 80$ & $I \cdot 58$ \\
\hline Suspension at $t_{5 \mathrm{~h}}$ & 5.02 & 一 & $6 \cdot 65$ & 0.224 \\
\hline Cell sap at $t_{\mathrm{f}}$ & $6 \cdot 12$ & 0.75 & $6 \cdot 12$ & 0.75 \\
\hline Disrupted at $t_{15 \min }$ & - & - & $6 \cdot 0 \mathrm{I}$ & 0.97 \\
\hline Cell sap at $t_{5 \mathrm{~h}}$ & $6 \cdot 12$ & 0.75 & $5 \cdot 20$ & $6 \cdot 31$ \\
\hline & Since & $-\log _{10}\left[\mathrm{H}^{+}\right]$ & & \\
\hline
\end{tabular}

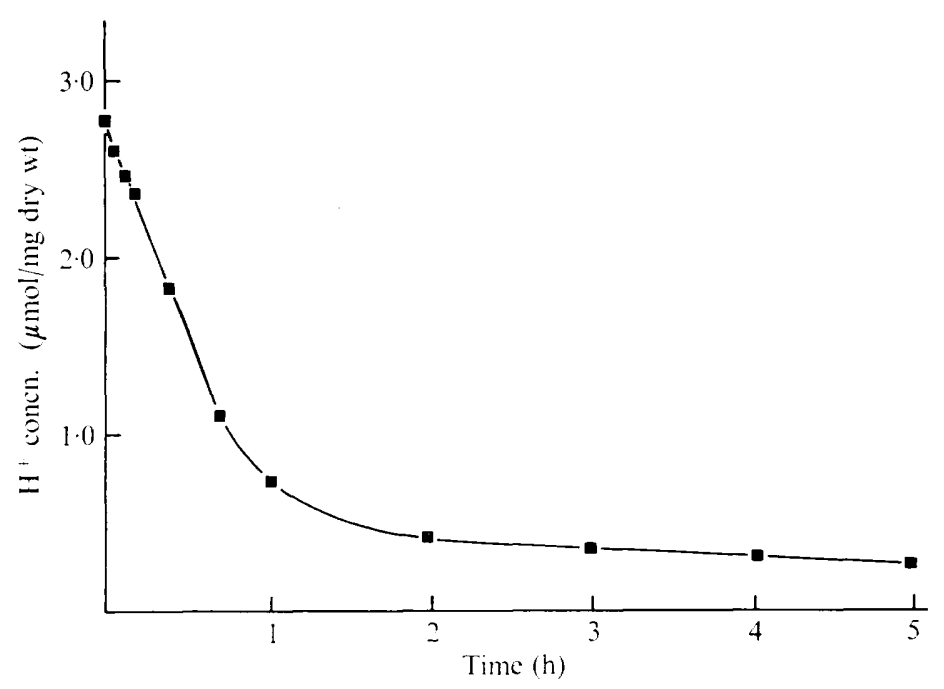

Fig. I. Loss of extracellular protons from a standard suspension of Candida albicans treated with $20 \mu \mathrm{g}$ candicidin $/ \mathrm{ml}$.

Similarly it can be calculated that the change in hydrogen ion concentration in the sap was $0.22 \mu$ equiv./mg dry wt and in the suspension I. OI $\mu$ equiv./mg dry wt at $t_{15 \text { min }}$.

From titration curves it was determined that the number of protons necessary to cause the $\mathrm{pH}$ change recorded in the cell sap was $8.9 \mu$ equiv./mg dry wt. From these curves it was also calculated that given the entry of $\mathrm{I} \cdot 0 \mu$ equiv. protons/mg (as at $t_{15 \mathrm{~mm}}$ ) the buffering capacity of the cytoplasm was such that the $\mathrm{H}^{+}$change would appear to be $0.2 \mu$ equiv./mg dry wt.

Table I shows that treatment with $20 \mu \mathrm{g}$ candicidin $/ \mathrm{ml}$ causes the organisms of the standard suspension to change in internal $\mathrm{pH}$ from $6 \cdot 12$ to $5 \cdot 20$. Fig. 2 demonstrates the change in $E$ caused in cell sap by equivalent acidification. There is a threefold increase in extinction which is irreversible.

Fig. 3 shows the normal appearance of Candida albicans after staining and fixing. Figs. 4 to 6 reveal the effect of two concentrations of candicidin on the morphology of C. albicans. Sub-lethal concentrations (Io $\mu \mathrm{g} / \mathrm{ml}$ ) of candicidin cause denser cytoplasm than 


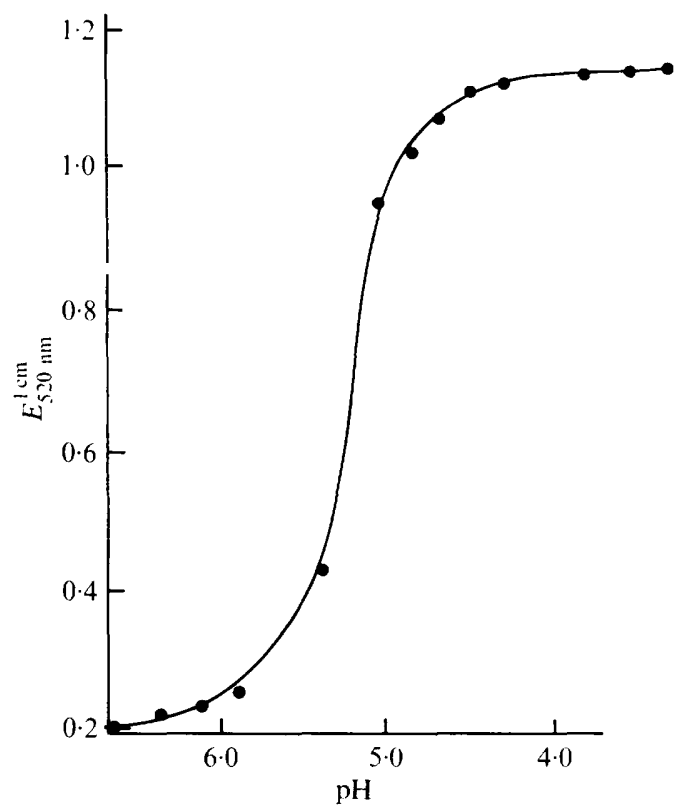

Fig. 2. Effect of pH upon turbidity of a cell-free cytoplasmic extract of Candida albicans.

normal, but some mitochondria and other organelles are still discernible. Lethal concentrations of candicidin cause complete organelle loss and marked granulation of the cytoplasm. Fig. 6 shows a parting of the cell membrane from the cell wall, a common phenomenon in candicidin-treated $C$. albicans cells.

\section{DISCUSSION}

Candicidin has the typical polyene property (Waksman, Lechevalier \& Schaffner, 1965) of binding to membrane sterols, so destroying membrane selective permeability. Lampen (I966) suggested that damage to the membrane allowed leakage of cations, predominantly potassium. The loss of these ions from yeast cells results in a change in internal charge and, if membrane permeability has been altered, one would expect the cations to be replaced (at a $\mathrm{pH}$ less than $7^{\circ} 0$ ) by protons from the environment.

This was established, the cytoplasm of Candida albicans becoming more acidic ( $\mathrm{pH} 6 \cdot \mathrm{I} 2$ becomes $\mathrm{pH} 5 \cdot 20$ ) concurrent with a loss of protons from the environment. The method of determination of internal cellular $\mathrm{pH}$, by determining the $\mathrm{pH}$ of cell sap, gives only a gross picture, but the values obtained agree with those of other authors, determined by other methods (Conway \& Downey, 1950).

Lampen (I966) suggested that a direct interchange of protons for lost $\mathrm{K}^{+}$ions occurs. Hammond et al. (1974), using specific ion electrodes, found that $\mathrm{K}^{+}$loss in C. albicans treated with candicidin was $0.33 \mu$ equiv./mg dry wt. Zygmunt (I966), by flame photometry, showed that a different strain of $C$. albicans lost $0.9 \mu$ equiv./mg dry wt when treated with lethal concentrations of candicidin. Venables \& Russell (1972), also by flame photometry, found that the polyene antibiotic nystatin caused leakage of $0.5 \mu \mathrm{equiv} . / \mathrm{mg}$. dry wt from Saccharomyces cerevisiae.

Under the experimental conditions, if there had only been a direct exchange of potassium ions for protons there would have been an almost negligible change in internal $\mathrm{pH}$. 


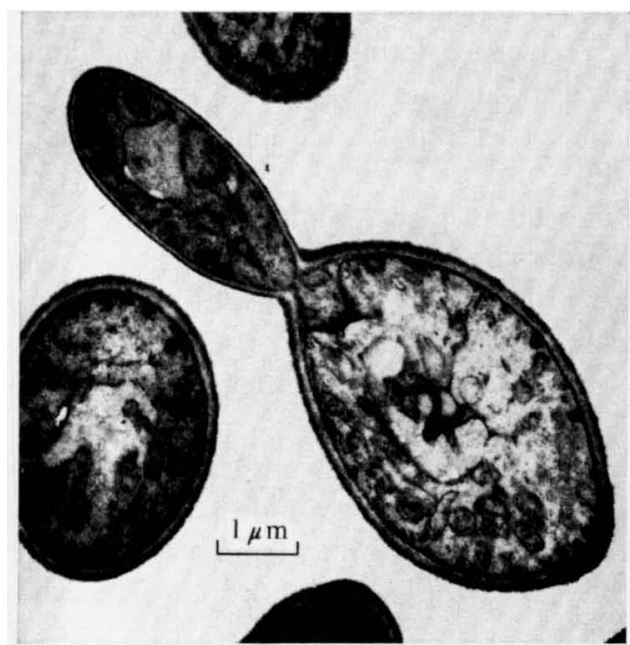

Fig. 3.

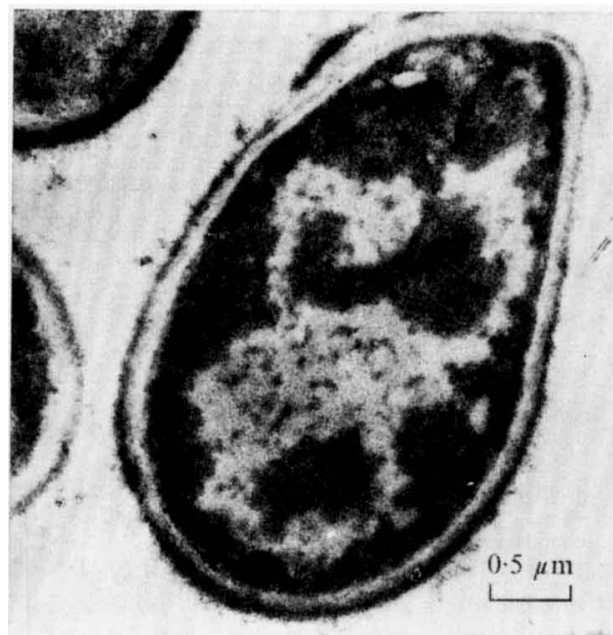

Fig. 5.

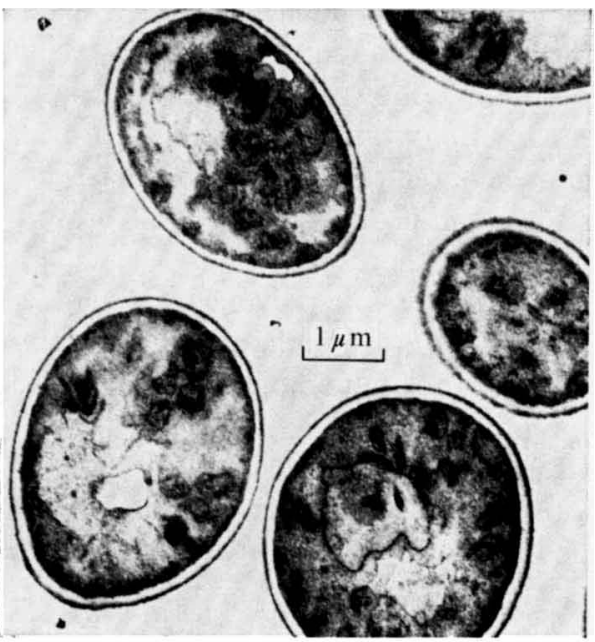

Fig. 4.

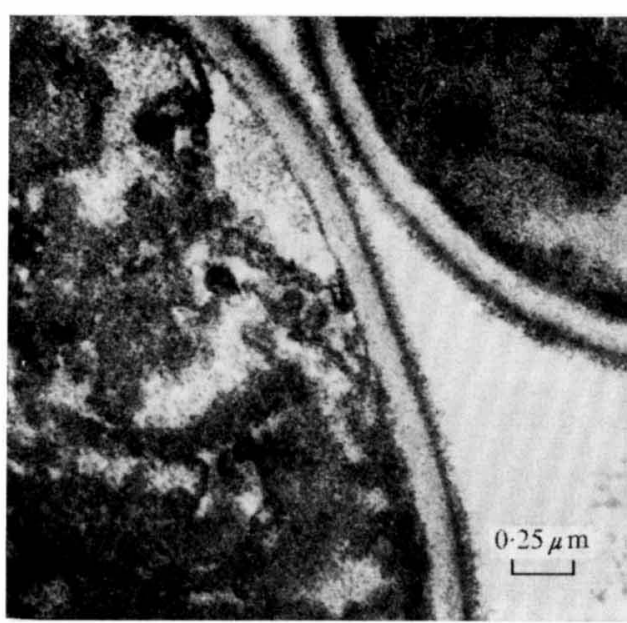

Fig. 6.

Fig. 3. Untreated Candida albicans fixed with permanganate.

Fig. 4. Candida albicans treated with $10 \mu \mathrm{g}$ candicidin $/ \mathrm{ml}$.

Fig. 5. Candida albicans treated with $20 \mu \mathrm{g}$ candidicin $/ \mathrm{ml}$.

Fig. 6. Candida albicans treated with $20 \mu \mathrm{g}$ candicidin/ml. Higher power view than Fig. 5, showing the membrane retracting from the cell wall.

In Candida albicans it takes up to $5 \mathrm{~h}$ for polyene-induced proton entry to be completed, while potassium efflux is completed in 15 to $20 \mathrm{~min}$ (Hammond et al. 1974; Venables \& Russell, 1972).

If membrane permeability has been altered by polyene action then it seems likely that small anions will diffuse out of the yeast organisms. Scholz, Schmitz, Bucher \& Lampen (I959) and Caltrider \& Gottlieb (I96I) reported phosphate leakage after polyene action. Ghosh \& Ghosh (1962) reported a $50 \%$ decrease in cell inorganic phosphate in Candida albicans 
after nystatin treatment, while Osteaux, Tran-Van-Ky \& Biquit (1958) detected leakage of carboxylic acids and phosphate esters. Cirrilo, Harsch \& Lampen (1964), using flamephotometry, showed phosphate leakage followed potassium leakage in baker's yeast treated with nystatin. This leakage of negatively charged species would tend to decrease the negative charge resulting from potassium leakage.

After 15 min only $4 \%$ of total proton entry had taken place, while potassium leakage had ceased. There was leakage of $0.33 \mu$ equiv. potassium ions $/ \mathrm{mg}$ dry wt from Candida albicans after $15 \mathrm{~min}$ polyene treatment, compared with loss of $\mathrm{I} \cdot \mathrm{OI} \mu$ equiv. of protons from the suspension. The major part of internal acidification must occur after the efflux of potassium ions is completed. This acidification is equivalent to the entry of $6.31 \mu$ equiv. $\mathrm{H}^{+} / \mathrm{mg}$ dry wt.

Other factors must account for proton entry in addition to potassium leakage. The loss of other cations has been reported and the leakage of these ions would create additional ionic imbalance causing proton entry. Alternatively some protons may be internal in origin. Conway \& Downey (1950) reported that the $\mathrm{pH}$ of yeast cytoplasm may drop to 5.8 in some organisms at certain stages in the life cycle. The internal production of carboxylic acids could also contribute to internal acidification. It is possible that the slight discrepancy in values obtained for protons leaving the environment and those causing internal acidification is due to the masking effect of leaking carboxylate ions.

The internal acidification caused by polyenes causes precipitation of cytoplasmic components and this was shown by precipitation of cell sap. The $\mathrm{pH}$ change induced by lethal concentrations of candicidin was sufficient to cause a marked increase in the extinction of cell sap in vitro. Venables \& Russell (1972), by light microscopy, observed an increase in granularity of yeasts after nystatin treatment. Marked granularity and organelle loss were observed by electron microscopy in cells treated with candicidin.

\section{REFERENCES}

Caltrider, P. \& Gotrlieb, D. (1961). Studies on the mode of action of filipin on S. cerevisiae. Transactions of the Illinois Academy of Science 54, 189-196.

CirRilo, V., HARSCH, M. \& LAMPEN, J. O. (1964). The action of polyene antibiotics on yeast cell membranes. Journal of General Microbiology 35, 249-259.

Conway, E. \& DownEY, A. (1950). The outer metabolic region of yeast cells. Biochemical Journal 47, 347-360.

Edebo, L. (196I). Disintegration by freeze pressing. II. Effects on fungi. Acta pathologica et microbiologica scandinavica 52, 371-368.

GALE, G. (1963). Cytology of C. albicans as influenced by drugs acting on the cytoplasmic membrane. Journal of Bacteriology 86, $15 \mathrm{I}-157$.

Grosh, A. \& GHOSH, J. (1962). Changes in the intracellular constituents on treatment with nystatin and amphotericin B. Annals of Biochemistry and Experimental Medicine 23, I1 3-122.

Hammond, S. M., LAMBerT, P. A. \& KLIGeR, B. N. (1974). The mode of action of polyene antibiotics; induced potassium leakage in C. albicans. Journal of General Microbiology 81, 325-330.

LAMPEN, J. O. (1966). Polyene antibiotics and membrane function. Symposia of the Society for General Microbiology 16, $111-130$.

Osteux, R., Tran-VAN-Ky \& Biquet, P. (1958). Contribution d'étude du mode d'action de la nystatine sur C. albicans. Comptes rendus des séances de l'Académie des sciences 247, 2475-2479.

Scholz, R., Schmitz, H., BuCHER, T. \& LAMPEN, J. O. (1959). Über die Wirkung von Nystatin auf Bäckerhefe. Biochemische Zeitschrift 331, 7I-74.

Venables, P. \& Russell, A. (1972). Some effects of nystatin on S. cerevisiae. Microbios 6, 239-246.

Waksman, S., LeChevalier, C. \& SChaffner, C. (1965). Candicidin and other polyene antibiotics. Bulletin of the World Health Organisation 33, 219-246.

ZyGmunt, W. (I966). Intracellular loss of potassium in C. albicans after exposure to polyene antibiotics. Applied Microbiology 14,953-956. 